\title{
POLÍTICA JURÍDICA, TRANSNACIONALIDADE E JURISDIÇÃO CONSTITUCIONAL
}

\author{
LEGAL POLITICS, TRANSNATIONALITY AND \\ CONSTITUTIONAL JURISDICTION
}

Lucas de Melo Prado*

\begin{abstract}
"Necessita-se o olhar de categorias inventadas que preparem as condições que realizem, para o futuro, o desejo do novo. A mediação de categorias que permitam sonhar o futuro." Luis Alberto Warat (2000, p. 193)
\end{abstract}

Sumário: Introdução. 1 Crise, Transição Paradigmática e Transnacionalidade. 2 Política Jurídica e Transnacionalidade. 3 Transconstitucionalismo e a Função Político-Jurídica da Jurisdição Constitucional na Pós-Modernidade. Considerações Finais. Referências das Fontes Citadas.

Resumo: O presente artigo parte da premissa de que, no atual estado de transição paradigmática, a transnacionalização do Direito é uma necessidade da Política Jurídica. Seu objetivo é analisar como a Jurisdição Constitucional pode funcionar como instrumento de uma Política Jurídica pós-moderna transnacional. Nesse mister, aborda a transição paradigmática da modernidade para a pós-modernidade, a necessidade de transnacionalização do Direito, os elementos basilares da Política Jurídica, a vocação político-jurídica da Jurisdição Constitucional e o Transconstitucionalismo. Ao final, conclui que a Jurisdição Constitucional, no âmbito de um Estado Transconstitucional de Direito, é ferramenta político jurídica chave para a construção da Sociedade pósmoderna que se deseja.

Palavras-chave:Política Jurídica. Jurisdição Constitucional. Transnacionalidade. Transconstitucionalismo.

\begin{abstract}
This essay assumes that the transnationalization of Law is a necessity of Legal Politics in the current state of paradigmatic transition. It aims to analyze how Constitutional Jurisdiction can be used as a tool of post modern transnational Legal Politics. To do so, it approaches the following topics: the paradigmatic transition from modernity to post modernity; the need of transnationalization of Law; the basic elements of Legal Politics; the legal and political calling of Constitutional Jurisdiction; and the Transconstitutionalism. In the end, the author comes to the conclusion that Constitutional Jurisdiction under a Transconstitutional State of Law is a key tool of Legal Politics in the construction of the desired post modern Society.
\end{abstract}

\footnotetext{
* Mestre em Ciência Jurídica pela Universidade do Vale do Itajaí - UNIVALI. Bacharel em Direito pela Universidade Federal do Piauí - UFPI. Professor colaborador da Universidade do Vale do Itajaí - UNIVALI. Email: prado.lm@gmail.com.
} 
Keywords: Legal Politics. Constitutional Jurisdiction. Transnationality. Transconstitutionalism.

\section{INTRODUÇÃO}

O presente artigo parte da premissa de que, no atual estado de transição paradigmática, a transnacionalização do Direito é uma necessidade político-jurídica. Seu objetivo é analisar de que forma a Jurisdição Constitucional pode se colocar na condição de instrumento de uma Política Jurídica pós-moderna transnacional, pondo-se a serviço da construção da Sociedade pós-moderna que se deseja.

Vale esclarecer, de início, que, ao se situar no âmbito da Política Jurídica, esta pesquisa já assume uma clara posição ideológica humanista, voltada à consecução dos anseios sociais e à persecução dos valores da Justiça, da Ética e da Estética no Direito e na Sociedade que se procura construir na pós-modernidade.

A fim de se alcançar o objetivo proposto, este artigo encontra-se organizado em três partes. Na primeira, esboça-se o atual estado de transição paradigmática, defendendo-se a necessidade de transnacionalização do Direito e destacando-se o papel da Política Jurídica na construção do paradigma pós-moderno. Na segunda parte, são explorados os elementos da Política Jurídica, esclarecendo-se que um projeto político-jurídico pós-moderno deve estar necessariamente vinculado aos valores da Justiça, da Ética e da Estética que fluem da convivência social. Por fim, na terceira parte, analisa-se o papel da Jurisdição Constitucional enquanto estratégia pós-moderna de Política Jurídica para a efetivação da Transnacionalização do Direito, a luz do Transconstitucionalismo.

Esta pesquisa possui como base teórica as lições de Política Jurídica de Osvaldo Ferreira de Melo, Maria das Graças dos Santos Dias e Moacyr Motta da Silva, bem como a teoria do Transconstitucionalismo de Marcelo Neves - esta, por sua vez, fortemente calcada na Teoria dos Sistemas de Niklas Luhmann.

Adotou-se, durante as fases de coleta e tratamento dos dados, a postura metodológica indutiva e realizou-se pesquisa bibliográfica, devidamente registrada pelo uso conjunto das técnicas do referente e do 
fichamento ${ }^{1}$, bem como da personalização das obras primárias, por meio de destaques e anotações nas próprias fontes de consulta ${ }^{2}$.

\section{CRISE, TRANSIÇÃO PARADIGMÁTICA E TRANSNACIONALIDADE}

Transição. Se o atual estado de coisas pudesse ser resumido em uma só palavra, certamente essa palavra seria "transição". A humanidade presencia e protagoniza, já há algum tempo, uma grande alteração em seus paradigmas epistemológico, institucional, estatal, científico, axiológico, jurídico, social, cultural etc. Durante esse longo processo, convivem, não raro conflitivamente, duas concepções de mundo: uma concepção moderna, que chega ao seu limite e, gradualmente, esgota suas capacidades de explicar e controlar o mundo da vida, transformando-se, pouco a pouco, em "um passado morto que não termina de morrer"; e uma concepção pós-moderna, na aurora de sua existência, ainda incerta, cambaleante, um produto em formação, "um futuro nascente que não consegue nascer" (MORIN; KERN, 2000, p. 102).

Nesse contexto, o Estado Moderno ${ }^{3}$, erigido sobre as bases da Soberania e da territorialidade, chega ao século XXI demonstrando claros sinais de exaustão.

As relações comerciais, em constante expansão, passam a adquirir contornos cada vez mais globalizados, principalmente após a derrocada do socialismo, no crepúsculo do século XX. As pressões do mercado

\footnotetext{
${ }^{1}$ Sobre a técnica do fichamento, bem como sobre seu uso conjunto com a técnica do referente, ver PASOLD, 2008, p. 53-62 e 107-123.

${ }^{2}$ Sobre o fichamento das fontes primárias, personalizando-se o livro com destaques e anotações, ver ECO, 2010, p. 94.

${ }^{3}$ Neste artigo, entende-se Estado Moderno ou Estado Constitucional Moderno como sendo a corporação de um povo, com Soberania assentada num determinado território, marcada pelo princípio da legalidade, a supremacia da Constituição, a tripartição dos poderes e a democracia representativa. Este conceito foi formulado a partir da definição de Estado proposto por George Jellinek (apud BONAVIDES, 2006, p. 71) — Estado é "[...] a corporação de um povo, assentada num determinado território e dotada de um poder originário de mando" - e do conceito de Estado Constitucional Moderno, proposto por Paulo Márcio Cruz e Zenildo Bodnar (2010, p. 56), segundo o qual "Estado Constitucional Moderno deve ser entendido como aquele tipo de organização política, surgida das revoluções burguesas e norte-americana nos séculos XVIII e XIX, que tiveram como principais características a soberania assentada sobre um território, a tripartição dos poderes e a paulatina implantação da democracia representativa."
} 
criam a necessidade de se construir um espaço mundial cada vez mais integrado e servem de impulso para avanços significativos, especialmente nas áreas da produção, transporte e comunicação. Na cauda do desenvolvimento técnico-científico, seguem as mudanças nas políticas econômicas dos Estados e o impulso em outras áreas, como a cultura, o turismo e a educação. (STELZER, 2010, p. 22-24). Essa relação entre comércio mundial e desenvolvimento técnico-científico se auto alimenta como uma bola de neve: enquanto o comércio incentiva novas descobertas tecnológicas, estas mesmas descobertas permitem uma maior expansão comercial — a qual, por sua vez, exige novos desenvolvimentos técnico-científicos. O resultado é uma intensificação jamais vista do processo de globalização, aqui entendido como "o crescente escopo e intensidade das relações comerciais, comunicativas e intercambiais para além das fronteiras nacionais" (HABERMAS, 2001, p. 66 , tradução livre) ${ }^{4}$.

Em meio a esse turbilhão, surgem novos espaços, que não se confundem nem com o nacional nem com o internacional: são espaços transnacionais. A imagem é de "rios transbordantes, que levam embora todas as barreiras alfandegárias e os controles de fronteiras e, em última instância, o bastião da própria nação" (HABERMAS, 2001, p. 67, tradução livre $)^{5}$. É importante destacar que, para os fins desta pesquisa, o "transnacional" não se confunde nem com o "internacional" nem com o "supranacional".

O "internacional" faz referência à comunidade mundial de Estados, estruturada a partir dos Tratados de Münster e Osnabrück de 1648 (conhecidos como Paz de Vestfália) e fundamentada nas concepções de Soberania ${ }^{6}$ e território ${ }^{7}$. Nesse contexto, os Estados coexistem em constante tensão e pautam suas ações com vista apenas às

4 Texto original em inglês: "the increasing scope and intensity of commercial, communicative, and exchange relations beyond national borders".

5 Texto original em inglês: "overflowing rivers, washing away all the frontier checkpoints and controls, and ultimately the bulwark of nation itself".

6 "O conceito político-jurídico de Soberania indica o poder de mando de última instância, numa sociedade política” (MATTEUCCI, 2008, p. 1179). A nível externo, isso significa a existência de numerosos poderes igualmente soberanos, que necessitam conviver uns com os outros, sem a presença de nenhuma autoridade supraestatal que lhes regule o comportamento (Soberania Externa).

7 "Definiu Pergolesi o território como 'a parte do globo terrestre na qual se acha efetivamente fixado o elemento populacional, com exclusão da soberania de qualquer outro Estado'." (BONAVIDES, 2006, p. 94). 
suas próprias razões de conveniência. A validade das obrigações internacionais está condicionada à vontade dos Estados. As normas internacionais são válidas porque os Estados escolhem se vincular a elas; e continuam válidas apenas enquanto os Estados aceitarem se submeter ao seu conteúdo ${ }^{8}$.

Já o "supranacional" relaciona-se com as comunidades regionais - em especial com a União Europeia. É o adjetivo reservado às instituições que estão acima dos Estados e que têm a capacidade de criar normas que os vinculem juridicamente. No estágio atual, são fenômenos estritamente regionais, posto que apenas a nível regional é possível formar-se artificialmente uma identidade coletiva para além das fronteiras - à semelhança da identidade nacional, forjada durante a formação dos Estados-Nação — , conferindo-se uma base de legitimidade e solidariedade às instituições supranacionais. A nível global, faltam as condições artificiais para o desenvolvimento dessa base de legitimidade para um pretenso (e, no presente momento, quimérico) governo mundial $^{9}$. (HABERMAS, 2001, 2004, 2006).

Afastando-se das concepção de "internacional" e "supranacional", o "transnacional" é o que se instaura para além das fronteiras, ou na fronteira transpassada, paralelamente ao Estado. Conforme salienta Gunther Teubner (2003), no âmbito jurídico, o "transnacional" adquire formas que não se confundem nem com os ordenamentos jurídicos nacionais, nem com o direito internacional clássico, nem com o direito comunitário supranacional. É um direito comum, construído a partir da Sociedade civil e compreendido adequadamente somente por meio de teorias pluralistas do Direito. Apresenta ordenamentos sui generis (lex mercatoria, lex sportiva internationalis, direitos humanos, direito ambiental), que não podem ser avaliados segundo os critérios de aferição de sistemas jurídicos nacionais.

\footnotetext{
${ }^{8}$ É certo que a teoria voluntarista, aqui utilizada não é a única que se presta a explicar o fundamento da obrigatoriedade do Direito Internacional. Contudo, independente do fundamento que se adote, a decisão do Estado de submeter-se a uma norma internacional, como consequência do corolário moderno da Soberania, continua sendo elemento indissociável da ordem jurídica internacional. Sobre os fundamentos da ordem jurídica internacional, v. ACCIOLY, 2009, v. 1, p. 36-62.

${ }^{9}$ Entende-se governo como a associação do "conjunto de pessoas que exercem o poder político e que determinam a orientação política de uma determinada sociedade" com "o complexo de órgãos que institucionalmente têm o exercício do poder” (LEVI, 2008, p. $553)$.
} 
Os espaços transnacionais vão além da concepção de Soberania e são marcados pela desterritorialização dos relacionamentos políticosociais e pela ultravalorização do sistema econômico capitalista, que articula ordenamento jurídico mundial à margem das Soberanias dos Estados. A desterritorialização é caracterizada pelo surgimento de um território transnacional, diverso tanto do espaço estatal quanto do espaço que liga dois ou mais espaços estatais, situando-se na "fronteira transpassada" ou na "borda permeável do Estado", e constituindo um espaço virtual não-contido, que não está lá nem cá - o que dificulta, por exemplo, a identificação do local exato de uma conversação em um chat virtual e, ao mesmo tempo, permite que a cadeia produtiva de uma empresa ocorra em mais de um Estado ou que um determinado serviço seja prestado em qualquer lugar do mundo. A ultravalorização do capitalismo é resultado do ritmo imposto por esse sistema econômico, que ganha força a partir do término da Segunda Guerra Mundial e expande-se em bases globais com o fim da Guerra Fria e a queda do bloco soviético, tornando a busca pelo lucro o espírito vetor do processo de globalização e o fator definidor das interações, tanto no plano interno quanto no externo, visando a acumulação de riquezas em escala global, proporcionada pela internacionalização do sistema produtivo. (STELZER, 2010, p. 24-31)

Essa nova dinâmica global, exatamente por não se limitar a nenhum território específico, mina o poder decisório do Estado Constitucional Moderno, que tem uma natureza intrinsecamente territorial. O Estado, sob a pressão dos mercados globalizados e na tentativa de acompanhar o desenvolvimento fomentado mundialmente, submete-se aos ditames econômicos globais, impostos pelo capitalismo globalizado e ultravalorizado, perdendo cada vez mais sua capacidade de influenciar os ciclos econômicos. A intensa mobilidade de capital promovida pela globalização econômica dificulta a própria funcionalidade do Estado, pois lhe impõe barreiras ao acesso à riqueza. $\mathrm{O}$ aumento da competição local reduz a capacidade estatal de coletar tributos e a mera ameaça de retirada de capital conduz a políticas de isenção tributária. (HABERMAS, 2001; BECK, 2005, 2006).

A globalização vem ainda acompanhada de riscos globais, fabricados colateralmente às decisões civilizacionais ${ }^{10}$. O poder aniquilador da bomba atômica; os desastres ambientais antropogênicos,

${ }^{10}$ Sobre a globalização dos riscos civilizacionais, v. BECK, 2005, 2006, 2009, 2010. 
como o acidente nuclear de Chernobyl; a invenção de aparelhos de alto risco, como o acelerador de partículas conhecido por LHC (Large Hadron Collider), capaz inclusive de produzir buracos negros; a devastação de ecossistemas inteiros, a exemplo da mata atlântica brasileira; o uso desenfreado dos recursos naturais; tudo isso demonstra o alcance e o impacto das ações humanas sobre a natureza, transcendendo as fronteiras nacionais e gerando riscos que se estendem a todos os recantos do globo terrestre.

A ineficácia das políticas públicas do Estado em fazer frente às mazelas sociais e aos problemas contemporâneos apontados acima demonstra a crise do paradigma moderno (DIAS, 2009, p. 14). Uma crise que não é apenas de responsabilidade do sistema capitalista, mas que resulta de toda uma concepção de mundo. (SABATO apud SILVA, 2009, p. 134).

A teorização de um novo modelo de organização jurídica e estatal, capaz de lidar com todas essas questões, é uma necessidade inarredável. Esse novo modelo, contudo, não está pronto, em um pretenso mundo de idéias, esperando ser encontrado. Na verdade, trata-se de um paradigma jurídico e estatal que ainda não existe e que ainda não foi criado (pelo menos, não completamente) e, por conseguinte, que ainda não adentrou no mundo da cultura.

A construção desse novo paradigma pós-moderno de Direito e de Estado não é tarefa (ao menos, não é tarefa direta) da Ciência do Direito. Esta cuida de responder "o que é e como é o Direito" (KELSEN, 2006, p. 1). A seu turno, a edificação de um novo paradigma jurídico e estatal relaciona-se com "a questão de saber como deve ser o Direito, ou como deve ele ser feito" (KELSEN, 2006, p. 1). É questão vinculada diretamente à Política do Direito - e apenas indiretamente à Ciência Jurídica, enquanto um dos momentos da análise político-jurídica.

\section{POLÍTICA JURÍDICA E TRANSNACIONALIDADE}

Por Política Jurídica (ou Política do Direito) entende-se a "disciplina que tem como objeto o Direito que deve ser e como deva ser, em oposição à Dogmática Jurídica, que trata da interpretação e da aplicação do Direito que é, ou seja, do Direito vigente". Nesse sentido, é um "conjunto de estratégias que visam à produção de conteúdo da norma, e sua adequação aos valores Justiça e Utilidade Social” (MELO, 2000, p. 77). 
Osvaldo Ferreira de Melo afirma que a Política Jurídica é "o mais adequado instrumental de que dispõe o jurista para participar do esforço de todos os cientistas sociais no direcionamento das mudanças sócioeconômicas, levando em conta as utopias da transmodernidade" (MELO, 1994, p. 47). Ela joga o papel fundamental de identificar as aspirações sociais, traduzindo-as em representações jurídicas que expressem o sentimento e o ideal de um modelo de Estado e de Direito desejáveis.

É função da Política Jurídica construir utopias. Isto é, forçar a ideologia ${ }^{11}$ a adentrar o campo da ação, desarticulando os paradigmas vigentes e pondo-se a serviço de uma estratégia de transformação. Nesse sentido, utopia não é quimera. São "projetos de transformação e mudança, [...] como projeção da sociedade que deve ser". Apresenta-se "não só como manifestações críticas em oposição aos paradigmas vigentes, mas também como projeções do que venham a ser bandeiras de luta" (MELO, 1994, p. 55). Utopia é, ao mesmo tempo, inconformismo com “o que é” e ideologia em ação (MELO, 2009, p. 88).

Essas representações utópicas não são mero fruto da fértil imaginação do político do Direito. Elas são o resultado da atividade político-jurídica de identificar os conteúdos normativos, os valores, os anseios, os desejos e os objetos aos quais se conecta a energia de vida da Sociedade. Tais aspirações sociais emergem de uma série de experiências históricas acumuladas, tradições culturais e alocações de valores, que formam a consciência jurídica social (MELO, 1998, p. 22). É nessa perspectiva que Moacyr Motta da Silva (2009, p. 138) assevera que "todo o acervo do conhecimento atropológico, ético, moral, político, sociológico é encontrado, em estado fragmentário, nas práticas sociais".

Gérard Timsit (apud DELMAS-MARTY, 2004, p. 116) mostra que o processo de geração do Direito passa por três figuras: a predeterminação, "que remete às condições de emissão da norma, ao legislador em sentido lato"; a co-determinação, "que resulta da margem deixada ao receptor a quem cabe aplicar a norma, ao juiz em sentido lato"; e a sobredeterminação, que corresponde ao "código de valores que se impõem no campo jurídico, tanto ao legislador como ao juiz, código cultural implícito ou [...] "uma lei que se expressa no silêncio"”. À Política Jurídica cabe identificar, nas aspirações e valores que fluem da

\footnotetext{
${ }^{11}$ Ideologia: "Num contexto político jurídico, conjunto de idéias, crenças e valores que orientam a escolha de alternativas e influenciam positiva ou negativamente a produção normativa e a formação da Consciência Jurídica Social.” (MELO, 2000, p. 49).
} 
convivência social, o conteúdo da sobredeterminação, garantindo que seus influxos atinjam os níveis de predeterminação (legislador) e codeterminação (juiz).

E se o Direito deve buscar o conteúdo da sobredeterminação nas aspirações e valores que fluem da convivência social, então a Ética e a Estética estarão presentes no julgamento axiológico de toda norma jurídica de caráter atributivo. Essa diretriz permite que ações de Política Jurídica estejam direcionadas para a edificação do Direito que deve ser e como deva ser (MELO, 2009, p. 72-73).

Em sua acepção político-jurídica, a Ética é compreendida “como valores fluídos de uma vivência grupal, comunitária, por isto empática e proxêmica" (DIAS, 2009, p. 22). É conduta esperada pela aplicação de valores morais no comportamento social e é fenômeno que surge "de um agir, de um comportamento consequencial, capaz de tornar possível e correta a convivência, dando-lhe inclusive o aporte estético" (MELO, 2009, p. 73).

Pela Estética da Convivência, a subjetividade abre-se à alteridade. "A multiplicidade de ações da pessoa, nos distintos grupos aos quais pertence, permite-lhe a vivência de múltiplas identificações — ao invés de uma única identidade" (DIAS, 2009, p. 20 e 22). É uma troca de panoramas. O indivíduo deixa de ser considerado de maneira solipsista (visão moderna) e passa a ser apreciado, primeiramente, dentro de grupos sociais específicos e, em um segundo momento, como parte integrante de toda a humanidade.

No atual momento de transição e convivência entre os paradigmas da modernidade e da pós-modernidade, a maior preocupação da Política do Direito é a construção de um devir em que Ética, Estética e os demais elementos do patrimônio espiritual da Sociedade (nível de sobredeterminação) não estejam condicionados à supremacia de questões tecnológicas e econômicas (MELO, 2009, p. 83). Ao mesmo tempo, as novas categorias a serem desenvolvidas pelo político do Direito devem ser capazes de lidar com os riscos civilizacionais, a crise ambiental e os demais problemas de caráter transnacional apontados anteriormente.

O projeto político-jurídico pós-moderno deve, assim, extrapolar as fronteiras estatais. Um modelo de cooperação mundial é imprescindível para o desenvolvimento da Sociedade desejável para a pós-modernidade. Nesse mister, os instrumentos internacionais e supranacionais são valiosas ferramentas da Política Jurídica na consecução de seus objetivos. Contudo, no contexto pós-nacional, são 
ferramentas imperfeitas. O padrão internacional vestifaliano está engessado pela Soberania e pelo voluntarismo estatal. O protótipo comunitário supranacional é ainda regionalizado e restrito a uma esfera territorial específica. A pós-modernidade demanda da Política Jurídica, além do "internacional" e do "supranacional", uma convergência com o "transnacional".

A fim de lidar com as questões contemporâneas transnacionais, as ações político-jurídicas devem revestir-se de caráter transnacional, buscando soluções também transnacionais, sob pena de absoluta ineficácia do novo paradigma social, estatal e jurídico que se procura desenvolver.

Como, então, promover transnacionalmente as ações políticojurídicas, pautadas nas aspirações sociais por um Estado e por um Direito fundamentados na Ética e na Estética da Convivência?

Retomando as categorias propostas por Timsit (predeterminação, co-determinação e sobredeterminação), a presente pesquisa faz a opção metodológica de analisar uma possível resposta a esse questionamento sob o prisma da co-determinação. Nessa linha de pensamento, buscar-seá, no próximo item, demonstrar como a Jurisdição Constitucional tem vocação político-jurídica nata e procurar-se-á explicar, a partir do Transconstitucionalismo, como ela pode servir de instrumento de operacionalização de ações político-jurídicas transnacionais.

\section{TRANSCONSTITUCIONALISMO E A FUNÇÃO POLÍTICO- JURÍDICA DA JURISDIÇÃO CONSTITUCIONAL NA PÓS- MODERNIDADE}

Até a modernidade, Direito e Política confundem-se em uma semântica moral-religiosa, em que bem e mal, transcendente e imanente, verdadeiro e falso, lícito e ilícito, poder e não poder, ter e não ter, belo e feio apontam sempre para uma estrutura de dominação político-social da "nobreza" sobre a "plebe". A nobreza identifica-se com os valores positivos do bem, do transcendente, do verdadeiro, do lícito, do poder, do ter e do belo, enquanto à plebe restam os valores negativos do mal, do imanente, do falso, do ilícito, do não poder, do não ter e do feio. (NEVES, 2009, p. 7).

O surgimento do Estado Moderno com as revoluções burguesas do século XVIII e, especialmente, a ascensão do Constitucionalismo significam a substituição do império dos homens pelo império das leis e 
o início do processo de diferenciação funcional entre Direito e Política (NEVES, 2009, p. 23). É a partir da modernidade que Direito e Política passam a seguir códigos binários distintos. Na teoria dos sistemas, o código binário é constituído por um elemento positivo e um elemento negativo, que não devem entrar em contradição e excluem outros elementos codificantes. Ele serve para diferenciar um sistema social do ambiente e dos demais sistemas sociais, bem como para assegurar a consistência interna do sistema. (LUHMANN, 1988/1989, p. 140).

Com o Estado Constitucional Moderno, o Direito estrutura-se segundo o código lícito/ilícito e a Política avoca o binômio poder/não poder. Dessa maneira, eles se diferenciam, assumindo funções sociais distintas. Conforme destaca Niklas Luhmann (2010) “esses sistemas servem para funções diferentes e assim projetam códigos e funções de modo diverso. São reciprocamente competentes, mas cada um em um sentido diferente".

Ademais, ao mesmo tempo que o Constitucionalismo é fenômeno determinante da diferenciação entre sistemas jurídico e político, ele é também uma reação à total separação entre ambos os sistemas, representando a necessidade de uma ligação entre eles (LUHMANN, 2010). A Constituição, a uma só vez, separa o Direito da Política e estabelece o seu acoplamento estrutural (LUHMANN, 1991/1992, p. 1436).

De acordo com Luhmann (1991/1992, p. 1432 e 1436, tradução livre), acoplamentos estruturais são "conexões altamente seletivas entre sistemas e ambientes". São filtros que controlam a entrada de perturbações, irritações, surpresas e desapontamentos causados entre sistemas. Por serem acoplamentos estruturais entre o sistema jurídico e o sistema político, as Constituições permitem que circunstâncias políticas concretas (e as possibilidades que tais circunstâncias criam para o uso instrumental de variações conceituais) ocasionem inovações históricas e mutações jurídicas. Por outro lado, "nenhum discurso político, nenhuma barganha política e nenhum planejamento de políticas públicas seria possível sem efeitos jurídicos imediatos" " ${ }^{12}$. Nessa medida, a Constituição legitima politicamente o direito, por meio dos processos democráticos, e legitima juridicamente a política, através do rule of law.

\footnotetext{
Textos originais em inglês: "highly selective connections between systems and environments" e "no polical discourse, no political bargaining, and no policy planning would be possible without immediate legal effects".
} 
Marcelo Neves (2009, p. 57) destaca que:

A Constituição, por um lado, torna o código-diferença "lícito/ilícito" relevante para o sistema político; isso implica que as exigências do Estado de direito e dos direitos fundamentais passam a constituir contornos estruturais da reprodução dos processo políticos de busca pelo poder e de tomada de decisões coletivamente vinculantes, inclusive na medida em que decisões majoritárias democraticamente deliberadas podem ser declaradas inconstitucionais. Por outro lado, torna o código-diferença "poder/não poder" ou, em termos contemporâneos, "governo/oposição" relevante para o sistema jurídico. Isso significa que o processo democrático de tomada de decisão política, no sentido de formação da maioria, passa a constituir variável estrutural da reprodução de conflitos, inclusive na medida em que a produção de normas jurídicas legislativas fica dependente das decisões políticas deliberadas democraticamente e tomadas majoritariamente.

Nesse diapasão, o âmbito constitucional é a área de re-encontro entre os sistemas jurídico e político e, exatamente por isso, tem uma vocação político-jurídica nata. Por conseguinte, a Jurisdição Constitucional, na qualidade de atividade jurídica que manuseia e transita nas veredas do acoplamento entre Direito e Política, é instrumento privilegiado da Política Jurídica.

Com essa função, a Jurisdição Constitucional joga um papel chave na realização de um devir pós-moderno desejável, fundamentado na Justiça, na Ética e na Estética da Convivência. Pela natureza de acoplamento estrutural de seu objeto, ela tem a aptidão natural de desarticular paradigmas, pôr ideologias em ação e construir utopias e estratégias de mudança no fazer político e, principalmente, no fazer jurídico.

Nada obstante, pelas razões expostas no item anterior, a efetividade político-jurídica pós-moderna da Jurisdição Constitucional está condicionada à necessidade de se lhe conferir um caráter transnacional. Mas, se a Constituição, como criação jurídica da modernidade, está vinculada ao Estado e, portanto, ao seu território, como pode a Jurisdição Constitucional desterritorializar-se e revestir-se de caráter transnacional? 
Em resposta a esse questionamento acorre a proposta de Transconstitucionalismo de Marcelo Neves (2009).

Neves defende que os acoplamentos estruturais, via de regra, permitem apenas o intercâmbio de elementos ou complexidades desordenadas. Esses elementos são racionalizados e ordenados somente após o intercâmbio sistêmico, já no interior do sistema receptor e dentro da lógica e das particularidades de seu código binário.

Alguns acoplamentos estruturais, contudo, permitem uma interpenetração sistêmica especial, não só dos elementos desordenados, mas de complexidades preordenadas pela racionalidade do sistema emissor e até da própria racionalidade desse sistema. Isso permite a formação de uma Racionalidade ou Razão Transversal, que entabula "mecanismos estruturais que possibilitam o intercâmbio construtivo de experiências entre racionalidades parciais diversas". Nessa linha, a Racionalidade Transversal "não é outorgada aos jogos de linguagem particulares, mas, ao contrário, está envolvida com entrelaçamentos que lhe servem como 'pontes de transição' entre heterogêneos" (NEVES, 2009, p. 38 e 39 respectivamente, itálicos no original).

Segundo Neves (2009, p. 62), as Constituições que desenvolvem a Racionalidade Transversal (Constituições Transversais) funcionam

não apenas como filtro das irritações e influências recíprocas entre sistemas autônomos de comunicação, mas também como instância da relação recíproca e duradoura de aprendizado e intercâmbio de experiências com as racionalidades particulares já processadas, respectivamente, na política e no direito.

As Constituições Transversais, ainda consoante Neves, possibilitam a construção de um Transconstitucionalismo que, por via de uma Racionalidade Transversal, estabelece relações entre ordens jurídicas de mesmo código binário primário (lícito/ilícito), mas com programas e critérios diversos. As "pontes de transição" entre essas diversas ordens jurídicas desenvolvem-se através de seus juízes e tribunais, mediante processos de "conversação" ou "diálogo" entre cortes, no bojo da Jurisdição Constitucional. Essas conversações estipulam, a rigor, comunicações transversais perpassando fronteiras entre ordens jurídicas. São fenômenos pontuais, articulados a partir de problemas jurídico-constitucionais que se apresentam simultaneamente a 
diversas ordens, não significando uma cooperação permanente entre as ordens jurídicas comunicantes. Além disso:

não cabe falar falar de uma estrutura hierárquica entre
ordens: a incorporação recíproca de conteúdos implica uma
releitura de sentido à luz da ordem receptora. Há
reconstrução de sentido, que envolve uma certa
desconstrução do outro e uma autodesconstrução: tanto
conteúdos de sentido do "outro" são desarticulados
(falsificados!) e rearticulados internamente, quanto
conteúdos de sentido originário da própria ordem são
desarticulados (falsificados!) e rearticulados em face da
introdução do "outro". (NEVES, 2009, p. 118)

Marcelo Neves ressalta que esse fenômeno surge do incremento das relações transnacionais que, tendo implicações normativas fundamentais, levam à necessidade de abertura do Constitucionalismo para além do Estado. Nesse sentido, problemas constitucionais transnacionais emergem nas mais diversas ordens jurídicas, exigindo soluções fundadas no entrelaçamento entre elas.

Nessa nova forma de Constitucionalismo, a lógica de funcionamento do Estado (ou, mais especificamente, de sua função jurisdicional) é sensivelmente alterada. A lei posta internamente deixa de ser o único marco jurídico válido para determinar o resultado de um caso apreciado judicialmente. A racionalidade de outras ordens constitucionais passam a perturbar, irritar e até alterar a racionalidade desenvolvida internamente. Essas mesmas ordens constitucionais que irradiam perturbações são também, a seu tempo, sistemas jurídicos receptores de perturbações de outras ordens constitucionais, quiçá daquelas mesmas ordens que havia recebido seus influxos em um outro momento. Esse fenômeno pode ser pontual e não criar vínculos permanentes entre sistemas jurídicos distintos, mas, com a frequência de sua ocorrência, não parece exagero afirmar que o Estado Constitucional Moderno se converte, gradualmente, em uma espécie de Estado Transconstitucional Pós-Moderno - assim chamado por estar fundamentado em uma Constituição Transnacional.

É por meio desse Transconstitucionalismo que a Jurisdição Constitucional tem possibilidades de entabular transnacionalmente as estratégias de Política Jurídica. Para tanto, é indispensável que o juiz constitucional adote a postura do político do Direito, identificando o 
conteúdo da sobredeterminação que flui dos anseios, desejos e valores da Sociedade transnacionalmente considerada, e permitindo que os influxos sobredeterminantes da Ética e da Estética da Convivência penetrem em sua atividade co-determinante de interpretação e aplicação do Direito o que só é possível, jurídica e politicamente, no âmbito de um Estado Transconstitucional de Direito.

\section{CONSIDERAÇÕES FINAIS}

A Sociedade contemporânea vive um momento de transição, com a crise do paradigma moderno e os esforços de criação de uma novo paradigma pós-moderno. Nesse contexto, a Política Jurídica, enquanto disciplina voltada ao Direito que deve ser, tem papel fundamental na construção da Sociedade pós-moderna que se deseja.

Pelos parâmetros político-jurídicos, identificados nas aspirações, desejos e valores historicamente consagrados no seio da Sociedade a nível de sobredeterminação, a Ética e a Estética da Convivência são essenciais para uma vivência grupal sadia e aberta à alteridade. Nessa perspectiva, o indivíduo sai da casta moderna solipsista e adentra a pósmodernidade como membro integrante da humanidade.

A efetividade desse projeto político-jurídico, ainda em construção, está condicionada à possibilidade de se transnacionalizar o Direito, para que ele possa lidar com as questões de caráter transnacional que surgem a partir da intensificação do processo de globalização.

A nível de co-determinação, defende-se que a Jurisdição Constitucional assume um papel chave nesse desiderato. Por manejar questões constitucionais, que estabelecem um acoplamento estrutural entre o sistema jurídico e o sistema político, a Jurisdição Constitucional apresenta-se com uma natural vocação para a Política do Direito.

A transnacionalização da Jurisdição Constitucional dá-se por meio da Racionalidade Transversal, que permite o intercâmbio de complexidades preordenada e racionalidades entre ordens jurídicas diversas, mas de mesmo código binário primário (lícito/ilítico). Esse fenômeno não estabelece um vínculo permanente entre as ordens comunicantes, mas a frequência com que ocorre contemporaneamente indica que o Estado Constitucional Moderno está paulatinamente se transformando em um Estado Transconstitucional Pós-Moderno.

Destarte, para que a Jurisdição Constitucional possa se colocar na condição de instrumento de uma Política Jurídica pós-moderna 
transnacional, pondo-se a serviço da construção da Sociedade pósmoderna que se deseja, fundamentada nos valores sobredeterminantes da Ética e da Estética da Convivência, faz-se necessário a sua inserção em um Estado Transconstitucional, que permita o intercâmbio de racionalidades entre diversos sistemas jurídicos.

\section{REFERÊNCIAS}

ACCIOLY, Hildebrando. Tratado de direito internacional público. 3. ed. São Paulo: Quartier Latin, 2009. v. 1.

BECK, Ulrich. Power in the global age. Tradução de Kathleen Cross. Cambridge, UK: Polity, 2005. Título original: Macht und Gegenmacht im globalen Zeitalter: neue weltpolitische Ökonomie.

Cosmopolitan vision. Tradução de Ciaran Cronin. Cambridge, UK: Polity, 2006. Título original: Der kosmopolitische Blick oder: Krieg ist Frieden.

. World at risk. Tradução de Ciaran Cronin. Cambridge, UK: Polity, 2009. Título original: Weltrisikogesellschaft.

Sociedade de risco: rumo a uma outra modernidade. Tradução de Sebastião Nascimento. São Paulo: Ed. 34, 2010. Título original: Risikogesellschaft: auf dem Weg in eine andere Moderne.

BONAVIDES, Paulo. Ciência política. 12. ed. São Paulo: Malheiros, 2006.

CRUZ, Paulo Márcio; BODNAR, Zenildo. A transnacionalidade e a emergência do estado e do direito transnacionais. In: CRUZ, Paulo Márcio; STELZER, Joana (Org.). Direito e transnacionalidade. Curitiba: Juruá, 2010. cap. 2.

DELMAS-MARTY, Mireille. Por um direito comum. Tradução de Maria Ermantina de Almeida Prado Galvão. São Paulo: Martins Fontes, 2004. Título original: Pour un droit commun. 
DIAS, Maria da Graça dos Santos. Direito e pós-modernidade. In: DIAS, Maria da Graça dos Santos; SILVA, Moacyr Motta da; MELO, Osvaldo Ferreira de. Política jurídica e pós-modernidade. Florianópolis: Conceito, 2009. p. 11-34.

ECO, Umberto. Como se faz uma tese. Tradução de Gilson Cesar Cardoso de Souza. 23. ed. São Paulo: Perspectiva, 2010. Título original: Come si fa una tesi di laurea.

HABERMAS, Jürgen. The postnational constellation and the future of democracy. In: . The postnational constellation: political essays. Tradução de Max Pensky. Cambridge, MA: MIT, 2001. p. 58-112. Título original: Die postnationale Konstellation: Politische Essays.

A idéia kantiana de paz perpétua: à distância histórica de 200 anos. In: . A inclusão do outro: estudos de teoria política. Tradução de George Sperber, Paulo Astor Soethe e Milton Camargo Mota. 2. ed. São Paulo: Lyola, 2004. cap. 7. p. 193-235. Título original: Die Einbeziehung des Anderen: Studien zur politischen Theorie.

O projeto kantiano e o ocidente dividido. In: O ocidente dividido. Tradução de Luciana Villas Bôas. Rio de Janeiro: Tempo Brasileiro, 2006. p. 115-204. Título original: Der gespaltene Westen.

KELSEN, Hans. Teoria pura do direito. Tradução de João Baptista Machado. 7. ed. São Paulo: Martins Fontes, 2006. Título original: Reine Rechtslehre.

LEVI, Lucio. Governo. In: BOBBIO, Norberto; MATTEUCCI, Nicola; PASQUINO, Gianfranco. Dicionário de política. Tradução de Carmen C. Varriale et al. 13. ed. Brasília: UnB, 2008. v. 1. p. 553-555. Título original: Dizionario di política.

LUHMANN, Niklas. Law as a social system. Northwestern University Law Review, v. 83, n. 1 e 2, p. 136-150, 1988/1989. 
. Operational closure and structural coupling: the differentiation of the legal system. Cardozo Law Review, v. 13, p. 1419-441, 1991/1992.

A constituição como aquisição evolutiva. [2010]. Disponível em: <http://www.scribd.com/doc/31253250/LUHMANN-Niklas-Aconstituicao-como-aquisicao-evolutiva>. Acesso em: 25 ago. 2012.

MATTEUCCI, Nicola. Soberania. In: BOBBIO, Norberto; PASQUINO, Gianfranco. Dicionário de política. Tradução de Carmen C. Varriale et al. 13. ed. Brasília: UnB, 2008. v. 2. p. 1179-1188. Título original: Dizionario di política.

MELO, Osvaldo Ferreira de. Fundamentos da política jurídica. Porto Alegre: Sérgio Antonio Fabris; CPGD-UFSC, 1994.

. Temas atuais de política do direito. Porto Alegre: Sérgio Antonio Fabris; CMCJ-UNIVALI, 1998.

. Dicionário de política jurídica. Florianópolis: OAB-SC, 2000.

. Ética e direito. In: DIAS, Maria da Graça dos Santos; SILVA, Moacyr Motta da; MELO, Osvaldo Ferreira de. Política jurídica e pósmodernidade. Florianópolis: Conceito, 2009. p. 71-79.

. O papel da política jurídica na construção normativa da pósmodernidade. In: DIAS, Maria da Graça dos Santos; SILVA, Moacyr Motta da; MELO, Osvaldo Ferreira de. Política jurídica e pósmodernidade. Florianópolis: Conceito, 2009. p. 81-94.

MORIN, Edgar; KERN, Anne Brigitte. Terra-pátria. Tradução de Paulo Azevedo Neves da Silva. 3. ed. Porto Alegre: Sulina, 2000. Título original: Terre-patrie.

NEVES, Marcelo. Transconstitucionalismo. São Paulo: WMF Martins Fontes, 2009.

PASOLD, Cesar Luiz. Metodologia da pesquisa jurídica: teoria e prática. 11. ed. rev. atual. Florianópolis: Conceito; Millennium, 2008. 
SILVA, Moacyr Motta da. Rumo ao pensamento jurídico da pósmodernidade. In: DIAS, Maria da Graça dos Santos; SILVA, Moacyr Motta da; MELO, Osvaldo Ferreira de. Política jurídica e pósmodernidade. Florianópolis: Conceito, 2009. p. 109-143.

STELZER, Joana. O fenômeno da transnacionalização da dimensão jurídica. In: CRUZ, Paulo Márcio; STELZER, Joana (Org.). Direito e transnacionalidade. Curitiba: Juruá, 2010. cap. 1.

TEUBNER, Gunther. A Bukowina global sobre a emergência de um pluralismo jurídico transnacional. Impulso, Piracicaba, v. 14, n. 33, p. 931, 2003.

WARAT, Luis Alberto. Por quem cantam as sereias: informe sobre ecocidadania, gênero e direito. Tradução de Julieta Rodrigues Saboia Cordeiro. Porto Alegre: Síntese, 2000. 